\title{
DOI: http://dx.doi.org/10.33846/sf11318
}

Uji Validitas dan Reliabilitas Leadership Behavior Inventory, Personal Mastery Questionnaire dan Kuesioner Kinerja Perawat di Rumah Sakit

Kornelis Nama Beni

Fakultas Keperawatan, Universitas Airlangga; kornelis.namabeni-2018@fkp.unair.ac.id

(koresponden)

Nursalam

Fakultas Keperawatan, Universitas Airlangga; nursalam@fkp.unair.ac.id

M. Hasinuddin

Sekolah Tinggi Ilmu Kesehatan Ngudia Husada Madura; hasin3333.nhm@ gmail.com

\begin{abstract}
Background: Measurement instruments play an important role in research, clinical practice, and health assessment. Measurement nurse leadership behavior, self-mastery and performance using the Leadership Behavior Inventory (LBI), Personal Mastery Questionnaire and nurse performance questionnaire in quality and patient safety. This instrument has been tested for validity and reliability. The aim of this study was to tested the validity and reliability of the Leadership Behavior Inventory, Personal Mastery questionnaire and nurse performance questionnaire in quality and patient safety. Method: This study was used quantitative study, a type of research tested questionnaire with a cross-sectional study design. Researchers was conducted validity and reliability tests. Respondents in this study were nurses who worked in hospitals in East Nusa Tenggara as many as 20 responden. The instruments tested were Leadership Behavior Inventory, Personal Mastery questionnaire and nurse performance questionnaire in quality and patient safety. Results: The results showed that the validity tested used Pearson product moment on 29 items of Leadership Behavior Inventory found values ( $r=0.539$-0.938), Cronbach alpha (0.9 75); 17 Personal mastery Questionnaire items were found ( $r=0.625$-0.902), Cronbach alpha (0.9 59); 23 nurse performance questionnaire items were found $(r$ = 0.714-0.942), Cronbach alpha (0.9 82); so that all items of this instrument was valid and reliable at a significance level of 0.0 5. Conclusion: Leadership Behavior Inventory Instrument, Personal Mastery Questionnaire and nurse performance questionnaire was valid and reliable to measured nurse leadership, personal mastery and nurse performance in quality and patient safety.
\end{abstract}

Keywords: LBI; Personal Mastery Questionnaire; nurse performance questionnaire

\begin{abstract}
ABSTRAK
Latar Belakang: Instrumen pengukuran memainkan peran penting dalam penelitian, praktik klinis, dan penilaian kesehatan. Pengukuran perilaku kepemimpinan perawat, penguasaan diri dan kinerja menggunakan Leadership Behavior Inventory, Personal Mastery Questionnaire dan kuesioner kinerja perawat dalam mutu dan keselamatan pasien. Instrumen dilakukan uji validitas dan reliabilitas. Tujuan penelitian ini menguji validitas dan reliabilitas Leadership Behavior Inventory, Personal Mastery questionnaire dan kuesioner kinerja perawat dalam mutu dan keselamatan pasien. Metode: Penelitian ini merupakan penelitian kuantitatif, jenis penelitian testing kuesioner dengan rancangan penelitian cross-sectional. Peneliti melakukan uji validitas dan reliabilitas. Responden dalam penelitian ini adalah perawat yang bekerja di Rumah Sakit di Nusa Tenggara Timur sebanyak 20 orang. Instrumen yang diuji adalah Leadership Behavior Inventory, Personal Mastery questionnaire dan kuesioner kinerja perawat dalam mutu dan keselamatan pasien. Hasil: Hasil uji validitas menggunakan Pearson product moment pada 29 item Leadership Behavior Inventory ditemukan nilai $(\mathrm{r}=$ 0.539 - 0.938), Cronbach alpha (0.975); 17 item Personal Mastery Questionnaire ditemukan $(\mathrm{r}=0.625-0.902)$, Cronbach alpha (0.959); 23 item kuesioner kinerja perawat ditemukan $(\mathrm{r}=0.714-0.942)$, Cronbach alpha (0.982); sehingga semua item instrumen ini adalah valid dan reliabel pada taraf signifikansi 0.05. Kesimpulan: Leadership Behavior Inventory, Personal Mastery Questionnaire dan kuesioner kinerja perawat telah memenuhi validitas dan reliabilitas untuk mengukur kepemimpinan, personal mastery perawat dan kinerja perawat dalam mutu dan keselamatan pasien.
\end{abstract}

Kata Kunci: LBI; Personal Mastery Questionnaire; kuesioner kinerja perawat

\section{PENDAHULUAN}

Instrumen pengukuran memainkan peran penting dalam penelitian, praktik klinis, dan penilaian kesehatan. Studi tentang kualitas instrumen ini memberikan bukti bagaimana penilaian properti dinilai, membantu peneliti memilih alat terbaik untuk digunakan. Keandalan dan validitas dianggap sebagai sifat pengukuran utama dari instrumen tersebut. Keandalan adalah kemampuan untuk mereproduksi hasil secara konsisten dalam waktu dan ruang. Validitas mengacu pada properti instrumen untuk mengukur dengan tepat apa yang diusulkannya. Penilaian sifat pengukuran instrumen berguna untuk mensubsidi pemilihan alat yang

313 Jurnal Penelitian Kesehatan Suara Forikes ------ http://forikes-ejournal.com/index.php/SF 
valid dan dapat diandalkan, untuk memastikan kualitas hasil studi ${ }^{(1)}$. Instrumen dikatakan valid saat dapat mengungkap data dari variabel secara tepat tidak menyimpang dari keadaan yang sebenarnya. Instrumen dikatakan reliabel saat dapat mengungkapkan data yang bisa dipercaya ${ }^{(2)}$. Prinsip validitas adalah pengukuran dan pengamatan yang berarti prinsip keandalan instrumen dalam mengumpulkan data. Validitas harus memenuhi dua unsur penting yaitu relevan isi instrumen dan relevan sasaran subjek dan cara pengukuran. Tes validitas ini adalah dikategorikan menjadi dua komponen besar yaitu; internal dan validitas eksternal. Validitas internal mengacu pada seberapa akurat ukuran yang didapat dari penelitian itu sebenarnya mengukur apa yang dirancang untuk mengukur. Sedangkan validitas eksternal mengacu pada seberapa akurat langkah-langkah yang diperoleh sampel penelitian menggambarkan populasi referensi dari dimana sampel penelitian diambil. Keandalan mengacu pada sejauh mana hasil diperoleh dengan pengukuran dan prosedur yang dapat direplikasi. Kurangnya keandalan mungkin timbul dari perbedaan antara pengamat atau instrumen pengukuran seperti kuesioner atau ketidakstabilan atribut yang sedang diukur yang akan selalu memengaruhi validitas daftar pertanyaan $^{(3)}$. Reliabilitas suatu instrumen dapat dilihat melalui stabilitas instrumen, ekuivalen dan homogenitas instrumen ${ }^{(4)}$.

Leadership Behavior Inventory (LBI) merupakan sebuah alat ukur untuk menilai keterlibatan individu dalam perilaku kepemimpinan transformasional. LBI terdiri dari lima faktor perilaku pemimpin yang akan di nilai oleh stafnya seberapa sering seorang pemimpin menggunakan perilaku tertentu. LBI menggunakan mencakup 29 item dengan skala Likert 8 poin di mana 1 (jarang) dan 8 (sangat sering). Berbagai penelitian telah menyoroti pentingnya memahami perbedaan dalam perilaku pemimpin lintas budaya. Leader Behavior Inventory (LBI) adalah salah satu ukuran perilaku kepemimpinan yang telah digunakan untuk menguji kepemimpinan di Amerika Serikat, Kosta Rika, Meksiko, dan Spanyol. LBI didasarkan pada lima faktor perilaku: memvisualisasikan kebesaran, memberdayakan, berkomunikasi, mengelola diri sendiri serta care dan pengakuan ${ }^{(5)}$. Personal mastery adalah salah satu disiplin dari pembelajaran organisasi yang berkesinambungan untuk mengklarifikasi dan memperdalam visi pribadi, fokus pada energi, pengembangan kesabaran dan melihat realitas secara lebih objektif ${ }^{(6)}$. Dimensi personal mastery terdiri dari visi pribadi, meningkatkan kreativitas, konflik struktural, kesadaran diri dan pengaturan diri.

Kinerja perawat dalam mutu dan keselamatan direkomendasikan oleh $\mathrm{IOM}^{(7)}$ yang diterapkan di semua rumah sakit di Indonesia, yang mencakup STEEEP: Safe/Aman: menghindari cedera pada pasien dari perawatan yang dimaksudkan untuk membantu mereka; Timely/Tepat waktu: mengurangi waktu menunggu dan terkadang keterlambatan berbahaya bagi mereka yang menerima dan mereka yang memberi perhatian ; Efektif: menyediakan layanan berdasarkan pengetahuan ilmiah untuk semua orang yang dapat mengambil manfaat dan menahan diri dari memberikan layanan kepada mereka yang tidak mungkin mendapatkan manfaat (menghindari penggunaan yang berlebihan dan berlebihan); Efisien: menghindari pemborosan, khususnya pemborosan peralatan, persediaan, ide, dan energy; Equitable/Pemerataan: adil, memberikan perawatan yang tidak berbeda dalam kualitas karena karakteristik pribadi seperti jenis kelamin, etnis, lokasi geografis, dan status sosial ekonomi; Person centered /Berpusat pada pasien: memberikan perawatan yang hormat dan responsif terhadap, preferensi, kebutuhan, dan nilai-nilai pasien individu dan memastikan bahwa nilai-nilai pasien memandu semua keputusan klinis. Nilai validitas dan reliabilitas suatu instrumen dipengaruhi oleh subjek yang diukur, pengguna instrumen, dan instrumen itu sendiri. Sehingga, validitas dan reliabilitas harus selalu diuji sebelum instrumen digunakan ${ }^{(8)}$. Tujuan dalam penelitian ini adalah menguji validitas dan reliabilitas instrumen Leadership Behavior Inventory, Personal Mastery Questionnaire dan kuesioner kinerja perawat dalam mutu dan keselamatan pasien.

\section{METODE}

Penelitian ini merupakan penelitian kuantitatif, jenis penelitian testing kuesioner dengan rancangan penelitian cross-sectional. Peneliti melakukan uji validitas dan reliabilitas. Responden dalam penelitian ini adalah perawat yang bekerja di Rumah Sakit di Nusa Tenggara Timur sebanyak 20 orang. Instrumen yang diuji adalah Leadership Behavior Inventory, Personal Mastery questionnaire dan kuesioner kinerja perawat dalam mutu dan keselamatan pasien. Leadership Behavior Inventory (LBI) dikembangkan oleh Howard Rudd Tom Kent Carrie A. Blair (2009) ${ }^{(5)}$. Peneliti sudah memperoleh izin menggunakan kuesioner. Jumlah pertanyaan sebanyak 29 skala Likert 1 s/d 8 Jarang: 1 dan 2 Kadang-kadang: 3 dan 4, Sering: 5 dan 6 dan Sangat sering: 7 dan 8. Personal mastery perawat yang terdiri dari lima dimensi yaitu visi pribadi, meningkatkan kreativitas, konflik struktural, kesadaran diri dan pengaturan diri. Personal mastery questionnaire dari Senge ${ }^{(9)}$ dan dikembangkan oleh peneliti dengan skala Likert yaitu sangat setuju (SS): 4, setuju (S):3, tidak setuju (TS): 2, sangat tidak setuju (STS): 1. Kuesioner kinerja perawat dalam mutu dan keselamatan yang meliputi 6 dimensi mutu dan keselamatan oleh Institute of Medicine Committee (2001) dikembangkan Shea Polancich dan peneliti dengan skala selalu: 4, sering: 3, jarang: 2 dan tidak pernah: $1^{(7)}$. Uji menggunakan SSPS IBM 25. Uji validitas menggunakan Pearson correlation dan uji reliabilitas menggunakan Cronbach alpha dengan tingkat signifikansi 0,05. 


\section{HASIL}

Uji validitas dan reliabilitas instrumen dilakukan pada tanggal 8-9 November 2019 pada 20 orang perawat di rumah sakit dengan hasil uji validitas dan reliabilitas instrumen antara lain:

\section{Uji Validitas dan Reliabilitas Leadership Behavior Inventory (LBI)}

Tabel 1. Hasil uji validitas dan reliabilitas kuesioner kepemimpinan

\begin{tabular}{|c|c|c|c|c|}
\hline No item & $\mathrm{R}$ tabel & $\mathrm{R}$ hasil & Keterangan & Alpha cronbach \\
\hline Item 1 & \multirow{29}{*}{$\begin{array}{l}\mathrm{N}=20 \text { orang } \\
\text { Sig } 0.05 \\
\mathrm{R} \text { tabel }=0.444\end{array}$} & 0.696 & Valid & \multirow{29}{*}{$\begin{array}{c}0.975 \\
\text { (reliabel) }\end{array}$} \\
\hline Item 2 & & 0.757 & Valid & \\
\hline Item 3 & & 0.770 & Valid & \\
\hline Item 4 & & 0.888 & Valid & \\
\hline Item 5 & & 0.814 & Valid & \\
\hline Item 6 & & 0.657 & Valid & \\
\hline Item 7 & & 0.741 & Valid & \\
\hline Item 8 & & 0.748 & Valid & \\
\hline Item 9 & & 0.653 & Valid & \\
\hline Item 10 & & 0.838 & Valid & \\
\hline Item 11 & & 0.539 & Valid & \\
\hline Item 12 & & 0.810 & Valid & \\
\hline Item 13 & & 0.683 & Valid & \\
\hline Item 14 & & 0.886 & Valid & \\
\hline Item 15 & & 0.813 & Valid & \\
\hline Item 16 & & 0.869 & Valid & \\
\hline Item 17 & & 0.898 & Valid & \\
\hline Item 18 & & 0.864 & Valid & \\
\hline Item 19 & & 0.796 & Valid & \\
\hline Item 20 & & 0.833 & Valid & \\
\hline Item 21 & & 0.938 & Valid & \\
\hline Item 22 & & 0.703 & Valid & \\
\hline Item 23 & & 0.877 & Valid & \\
\hline Item 24 & & 0.817 & Valid & \\
\hline Item 25 & & 0.918 & Valid & \\
\hline Item 26 & & 0.826 & Valid & \\
\hline Item 27 & & 0.651 & Valid & \\
\hline Item 28 & & 0.745 & Valid & \\
\hline Item 29 & & 0.542 & Valid & \\
\hline
\end{tabular}

Berdasarkan hasil pada tabel 1 diatas dapat dijelaskan bahwa semua item kuesioner LBI adalah valid untuk digunakan dalam pengukuran kepemimpinan dengan nilai $r$ hitung $>r$ tabel 0,444. Reliabilitas kuesioner sangat reliabel dengan nilai Cronbach alpha sebesar 0,975 dengan tingkat signifikansi 0,05.

\section{Uji Validitas dan Reliabilitas Personal Mastery Questionnaire}

Tabel 2. Hasil uji validitas dan reliabilitas kuesioner personal mastery perawat

\begin{tabular}{|c|c|c|c|c|}
\hline No item & $\mathrm{R}$ tabel & $\mathrm{R}$ hasil & Keterangan & Alpha cronbach \\
\hline Item 1 & \multirow{17}{*}{$\begin{array}{l}\mathrm{N}=20 \text { orang } \\
\text { Sig } 0,05 \\
\mathrm{R} \text { tabel }=0,444\end{array}$} & 0,820 & Valid & \multirow{17}{*}{$\begin{array}{c}0,959 \\
\text { (reliabel) }\end{array}$} \\
\hline Item 2 & & 0,862 & Valid & \\
\hline Item 3 & & 0,902 & Valid & \\
\hline Item 4 & & 0,722 & Valid & \\
\hline Item 5 & & 0,730 & Valid & \\
\hline Item 6 & & 0,873 & Valid & \\
\hline Item 7 & & 0,704 & Valid & \\
\hline Item 8 & & 0,804 & Valid & \\
\hline Item 9 & & 0,691 & Valid & \\
\hline Item 10 & & 0,712 & Valid & \\
\hline Item 11 & & 0,827 & Valid & \\
\hline Item 12 & & 0,848 & Valid & \\
\hline Item 13 & & 0,786 & Valid & \\
\hline Item 14 & & 0,708 & Valid & \\
\hline Item 15 & & 0,761 & Valid & \\
\hline Item 16 & & 0,625 & Valid & \\
\hline Item 17 & & 0,747 & Valid & \\
\hline
\end{tabular}

Berdasarkan tabel 2 diatas hasil uji validitas dan reliabilitas kuesioner personal mastery perawat dapat diketahui bahwa semua item pernyataan valid dengan nilai $r$ hitung $>r$ tabel 0.444 . Reliabilitas dari kuesioner ini adalah 0.959 dengan tingkat signifikansi 0.05 . 


\section{Uji Validitas dan Reliabilitas Kuesioner Kinerja Perawat Dalam Mutu dan Keselamatan Pasien}

Tabel 3. Hasil uji validitas dan reliabilitas kuesioner kinerja perawat dalam mutu dan keselamatan

\begin{tabular}{|c|c|c|c|c|}
\hline No item & $\mathrm{R}$ tabel & $\mathrm{R}$ hasil & Keterangan & Alpha cronbach \\
\hline Item 1 & \multirow{23}{*}{$\begin{array}{l}\mathrm{N}=20 \text { orang } \\
\text { Sig } 0.05 \\
\mathrm{R} \text { tabel }=0.444\end{array}$} & 0.797 & Valid & \multirow{23}{*}{$\begin{array}{c}0.982 \\
\text { (reliabel) }\end{array}$} \\
\hline Item 2 & & 0.714 & Valid & \\
\hline Item 3 & & 0.763 & Valid & \\
\hline Item 4 & & 0.754 & Valid & \\
\hline Item 5 & & 0.768 & Valid & \\
\hline Item 6 & & 0.860 & Valid & \\
\hline Item 7 & & 0.901 & Valid & \\
\hline Item 8 & & 0.863 & Valid & \\
\hline Item 9 & & 0.897 & Valid & \\
\hline Item 10 & & 0.847 & Valid & \\
\hline Item 11 & & 0.854 & Valid & \\
\hline Item 12 & & 0.942 & Valid & \\
\hline Item 13 & & 0.921 & Valid & \\
\hline Item 14 & & 0.874 & Valid & \\
\hline Item 15 & & 0.850 & Valid & \\
\hline Item 16 & & 0.942 & Valid & \\
\hline Item 17 & & 0.921 & Valid & \\
\hline Item 18 & & 0.902 & Valid & \\
\hline Item 19 & & 0.762 & Valid & \\
\hline Item 20 & & 0.902 & Valid & \\
\hline Item 21 & & 0.902 & Valid & \\
\hline Item 22 & & 0.784 & Valid & \\
\hline Item 23 & & 0.812 & Valid & \\
\hline
\end{tabular}

Berdasarkan tabel 3 diatas hasil uji validitas dan reliabilitas kuesioner kinerja perawat dalam mutu dan keselamatan pasien dapat diketahui bahwa semua item pernyataan valid dengan nilai $r$ hitung $>r$ tabel 0.444 . Reliabilitas dari kuesioner ini adalah 0.982 dengan tingkat signifikansi 0.05 .

\section{PEMBAHASAN}

Validitas adalah pengukuran dan pengamatan yang berarti keandalan instrument dalam mengumpulkan data ${ }^{(4)}$. Uji validitas berguna untuk mengetahui apakah ada pernyataan pada kuesioner yang harus dibuang/diganti karena dianggap tidak relevan. Kategori pertama adalah validitas konten. Kategori ini melihat apakah instrumen tersebut secara memadai mencakup semua konten yang harusnya berkenaan dengan variabel. Validitas construct mengacu pada apakah peneliti dapat menggambar kesimpulan tentang nilai tes yang terkait dengan konsep sedang dipelajari ${ }^{(10)}$. Uji validitas dengan melihat nilai tiap item pernyataan dimana item instrument dinyatakan valid jika $\mathrm{R}$ hitung/hasil > R tabel. Reliabilitas adalah kemampuan untuk mereproduksi hasil yang konsisten dalam waktu dan ruang, atau dari pengamat yang berbeda, menghadirkan aspek koherensi, stabilitas, kesetaraan, dan homogenitas. Ini adalah salah satu kriteria kualitas utama suatu instrumen ${ }^{(1)}$. Uji reliabilitas berguna untuk menetapkan apakah instrumen yang dalam hal ini kuesioner dapat digunakan lebih dari satu kali, paling tidak oleh responden yang sama akan menghasilkan data yang konsisten. Reliabilitas instrumen diperlukan untuk mendapatkan data sesuai dengan tujuan pengukuran. Untuk mencapai hal tersebut, dilakukan uji reliabilitas dengan menggunakan metode alpha cronbach diukur berdasarkan skala alpha cronbach 0 sampai 1.

Hasil penelitian menunjukkan bahwa Leadership Behavior Inventory memiliki nilai validitas lebih besar dari $r$ tabel. Hal ini menunjukkan bahwa instrumen ini sangat valid untuk digunakan sebagai pengukuran kepemimpinan perawat di rumah sakit. Item 1-6 menggambarkan perilaku kepemimpinan visualisasi kebesaran yaitu melibatkan perilaku yang terkait dengan menciptakan dan mengomunikasikan visi yang menginspirasi. Item pertanyaan 7-14 menggambarkan perilaku pemimpin yang memberdayakan termasuk perilaku yang menciptakan rasa "kesatuan" di antara pengikut. Item pertanyaan 15-20 menggambarkan perilaku pemimpin dalam memberi arti berkomunikasi yaitu berfokus pada melintasi nilai atau relevansi ide, keputusan, dan strategi penting. Item 21-25 menggambarkan perilaku pemimpin yang mengelola "diri" seseorang berhubungan dengan pemimpin yang mempertahankan ketekunan, fokus, dan disiplin diri. Item pertanyaan 26-29 menggambarkan perilaku care dan pengakuan menunjukkan perhatian dan rasa terima kasih yang tulus atas kerja keras dan upaya orang-orang. Semua item pertanyaan sangat reliabel untuk digunakan sebagai pengukuran perilaku kepemimpinan di rumah sakit. LBI berguna karena menggabungkan perilaku yang terdiri dari apa yang penulis utama gambarkan sebagai kepemimpinan transformasional ${ }^{(5)}$. Penelitian ini difokuskan pada persepsi bawahan terhadap para pemimpin sebagai masukan untuk peningkatan fungsi kepemimpinan. Para pemimpin di setiap level memainkan peran sentral dalam perubahan sehingga persepsi perawat terhadap perilaku pemimpin sangat dibutuhkan untuk meningkatkan kinerja perawat ${ }^{(11)}$. Hasil 
penelitian awal ini menunjukkan bahwa LBI sangat diperlukan untuk mengukur persepsi bawahan terhadap fungsi kepemimpinan yang mencakup visualisasi kekuatan, pemberdayaan, komunikasi, pengelolaan perawat dan perilaku care. Memperlakukan beragam individu dengan rasa hormat dapat berkorelasi erat dengan kecenderungan pemimpin untuk melibatkan orang lebih penuh dalam upaya perubahan. Keberhasilan persepsi bawahan yang positif terhadap fungsi kepemimpinan berhubungan dengan perubahan fungsi kepemimpinan (11). Nilai skor yang tinggi pada visualisasi kebesaran menggambarkan bahwa responden memiliki persepsi tentang pemimpin yang memiliki visi organisasi yang terarah serta mampu mengomunikasikan dan memotivasi staff untuk mencapai visi bersama. Nilai skor pada pemberdayaan menggambarkan bahwa responden memiliki persepsi yang positif tentang pemimpin yang memiliki komitmen pemberdayaan terhadap team dalam melaksanakan tugas perencanaan, koordinasi dan komunikasi dalam team. Nilai skor yang tinggi pada memberi arti berkomunikasi menggambarkan bahwa responden memiliki persepsi positif tentang pemimpin yang mampu memberi arti dalam berkomunikasi tentang visi dan proses untuk mencapai visi bersama. Nilai skor tinggi pada perilaku pemimpin dalam pengelolaan diri menggambarkan bahwa responden memiliki persepsi positif tentang pemimpin yang memiliki tujuan dan selalu menjaga pikiran dan emosi untuk tetap fokus dan konsisten dalam mencapai tujuan. Sedangkan nilai skor tinggi pada perilaku care menggambarkan pemimpin yang peduli dan memberikan penghargaan atas pencapaian tujuan bersama damal team (5), (12). Leadership Behavior Inventory (LBI) memiliki sifat psikometrik yang baik. Validitas dan reliabilitas instrumen LBI dari lima skala perilaku kepemimpinan sangat bagus dan secara konsisten kuat untuk diterapkan pada populasi sampel. Faktor yang mendasari kuatnya instrumen ini dapat diterapkan di rumah sakit karena adanya kepemimpinan berjenjang. Rumah sakit menerapkan jenjang kepemimpinan terkecil yaitu kepala ruangan yang dapat dinilai perilakunya oleh staff di ruangan ${ }^{(13)(14)}$.

Hasil penelitian menunjukkan bahwa personal mastery kuesioner memiliki nilai validitas lebih besar dari $\mathrm{r}$ tabel. Hal ini menunjukkan bahwa instrumen ini sangat valid untuk digunakan sebagai pengukuran personal mastery perawat di rumah sakit. Dari item pernyataan 1-4 menggambarkan dimensi visi pribadi yaitu keinginan intrinsik perawat mengenai masa depan mutu dan pelayanan yang mempunyai makna muncul dalam pikiran serta berkomitmen untuk mencapai kualitas pelayanan; item 5-8 menggambarkan dimensi creative tension yaitu tingkat kemampuan perawat menyalurkan energi dari adanya kesenjangan antara visi pribadi perawat; item 9-11 menggambarkan dimensi konflik struktural yaitu kesediaan perawat dengan kesadaran mengubah keyakinan terhadap ketidak mampuan dan meningkatkan kekuatan; item 12-14 menggambarkan dimensi kesadaran diri yaitu kemampuan perawat dalam memberi persepsi pentingnya peningkatan mutu dan keselamatan pasien serta menerapkan perilaku/tindakan yang membantu dalam peningkatan mutu dan keselamatan pasien; dan item 15-17 menggambarkan dimensi pengaturan diri yaitu kemampuan perawat mengendalikan perhatian, kognisi, emosi dan tindakan ${ }^{(15)}$. Visi pribadi merupakan landasan untuk penguasaan pribadi yang terus berkembang. Pengembangan instrumen visi pribadi yang berisi pernyataan penetapan tujuan, kejelasan tujuan dan upaya mencapai tujuan pribadi. Pengembangan instrumen creative tension berisi peningkatan kemampuan dan memberikan solusi yang tepat untuk mengatasi masalah. Instrumen konflik struktural dikembangkan dari kesadaran dan komitmen terhadap kebenaran ${ }^{(16)}$. Instrumen kesadaran diri dan pengaturan diri dikembangkan dari kecerdasan emosional yang harus dimiliki oleh staff di rumah sakit ${ }^{(17)}$. Bagian dari penguasaan pribadi yaitu visi pribadi, ketegangan kreatif dan konflik struktural adalah kemampuan proses pengembangan diri seseorang secara terus-menerus selalu mencari cara untuk terus berkembang, untuk mendapatkan hal-hal baru untuk dipelajari, dan untuk membuat perubahan ${ }^{(18)}$. Semua item pertanyaan sangat valid dan reliabel untuk digunakan dalam pengukuran personal mastery perawat di rumah sakit.

Hasil penelitian menunjukkan bahwa kuesioner kinerja perawat dalam mutu dan keselamatan pasien memiliki nilai validitas lebih besar dari $r$ tabel. Hal ini menunjukkan bahwa instrumen ini sangat valid untuk digunakan sebagai pengukuran kinerja perawat di rumah sakit. Item 1-6 menggambarkan dimensi kinerja safe; item 7-8 menggambarkan dimensi kinerja timely; item 9-12 menggambarkan dimensi kinerja effective; item 13-15 menggambarkan dimensi kinerja efisien; item 16-17 menggambarkan dimensi kinerja equitable, dan item 18-23 menggambarkan dimensi kinerja person centered. Prinsip dalam penilaian kinerja yang dijadikan acuan adalah objektif, realistis, tepat waktu, dapat dipertanggung jawabkan, terukur, terbuka dan tidak diskriminatif. Proses penilaian kinerja dapat digunakan secara efektif dalam mengarahkan perilaku pegawai dalam rangka menghasilkan jasa keperawatan dalam kualitas dan volume yang tinggi ${ }^{(19)}$. Kualitas mutu dan keselamatan yang diterapkan di semua rumah sakit yang mencakup STEEEP: Safe/Aman: menghindari cedera pada pasien dari perawatan yang dimaksudkan untuk membantu mereka, Timely/Tepat waktu: mengurangi waktu menunggu dan terkadang keterlambatan berbahaya bagi mereka yang menerima dan mereka yang memberi perhatian, Efektif: menyediakan layanan berdasarkan pengetahuan ilmiah untuk semua orang yang dapat mengambil manfaat dan menahan diri dari memberikan layanan kepada mereka yang tidak mungkin mendapatkan manfaat (menghindari penggunaan yang berlebihan dan berlebihan), Efisien: menghindari pemborosan, khususnya pemborosan peralatan, persediaan, ide, dan energi; Equitable/Pemerataan: adil, memberikan perawatan yang tidak berbeda dalam kualitas karena karakteristik pribadi seperti jenis kelamin, etnis, lokasi geografis, dan status sosial ekonomi dan Person centered/Berpusat pada pasien: memberikan 
perawatan yang hormat dan responsif terhadap, preferensi, kebutuhan, dan nilai-nilai pasien individu dan memastikan bahwa nilai-nilai pasien memandu semua keputusan klinis ${ }^{(7)}$. Semua item pertanyaan sangat reliabel untuk digunakan dalam pengukuran kinerja perawat dalam mutu dan keselamatan pasien di rumah sakit.

\section{KESIMPULAN}

Instrumen memiliki kedudukan yang penting dalam penelitian karena instrumen berperan dalam proses pengambilan data. Instrumen yang valid dan reliabel dapat menghasilkan data yang valid dan reliabel pula sehingga membawa pada kesimpulan yang sesuai dengan keadaan sebenarnya. Instrumen Leadership Behavior Inventory, Personal Mastery Questionnaire dan kuesioner kinerja perawat dalam mutu dan keselamatan pasien memiliki nilai yang valid dan reliabel untuk digunakan sebagai instrumen pengukuran terhadap kepemimpinan, personal mastery dan kinerja perawat di rumah sakit. Penelitian ini adalah langkah penting dalam mengembangkan ukuran perilaku pemimpin di rumah sakit, penguasaan pribadi yang harus dimiliki oleh perawat dan kinerja perawat yang diharapkan dalam pelayanan. Penelitian di masa depan harus mengeksplorasi cara meningkatkan variabilitas dalam respon dengan melibatkan cakupan responden lebih dari 20 responden untuk mengukur validitas dan keandalan instrumen ini. Selain itu, eksplorasi lebih lanjut terhadap peningkatan perilaku pemimpin dalam perubahan organisasi, penguasaan pribadi yang mendukung peningkatan kinerja perawat dalam mutu dan keselamatan pasien di rumah sakit.

\section{DAFTAR PUSTAKA}

1. Souza AC de, Alexandre NMC, Guirardello E de B. Propriedades psicométricas na avaliação de instrumentos: avaliação da confiabilidade e da validade. Epidemiol e Serv saude Rev do Sist Unico Saude do Bras. 2017;26(3):649-59.

2. Arikunto S. Prosedur penelitian: suatu pendekatan praktik. Jakarta: Rineka Cipta; 2010.

3. Bolarinwa $\mathrm{O}$. Principles and methods of validity and reliability testing of questionnaires used in social and health science researches. Niger Postgrad Med J. 2015;22(4):195.

4. Nursalam. Metodologi Penelitian Ilmu Keperawatan: Pendekatan praktis. Edisi 4. Jakarta: Salemba Medika; 2017.

5. Howard Rudd Tom Kent Carrie A. Blair. Leader Behavior Inventory: A Test of Measure Equivalence in Germany and the United States. Int J Leadersh Stud. 2009;5(1):22-36.

6. Peter Senge. The Fifth Discipline: The Art and Practice of the Learning Organization. 2nd ed. London: Random House; 2006.

7. Institute of Medicine Committee. Crossing the quality chasm: A new health system for the 21 st century. Washington, DC [Internet]. USA; 2001. Available from: http://iom.nationalacademies.org/Reports/2001/Crossing-the-Quality-Chasm-A-New-Health-System-for-the21st-Century.aspx

8. Mohamad MM, Sulaiman NL, Sern LC, Salleh KM. Measuring the Validity and Reliability of Research Instruments. Procedia - Soc Behav Sci [Internet]. 2015;204(November 2014):164-71. Available from: http://dx.doi.org/10.1016/j.sbspro.2015.08.129

9. Senge P. The Fifth Discipline The Art And Practice Of The Learning Organization. C U R R E N C Y; 1990.

10. Heale R, Twycross A. Validity and reliability in quantitative studies. Evid Based Nurs. 2015;18(3):66-7.

11. Stilwell RA, Pasmore WA, Shon DH. Change Leader Behavior Inventory: Development and Validation of an Assessment Instrument. J Appl Behav Sci. 2016;52(4):373-95.

12. Kasemaa A, Liik K, Meerits A. The Initial Results Of Adopting The Transformational- Transactional Leadership Inventory. 2016;1:74-95.

13. Posner B. Investigating the Reliability and Validity of the Leadership Practices Inventory®. Adm Sci. 2016;6(4):17.

14. Nursalam N, Fibriansari RD, Yuwono SR, Hadi M, Efendi F, Bushy A. Development of an empowerment model for burnout syndrome and quality of nursing work life in Indonesia. Int J Nurs Sci [nternet]. 2018;5(4):390-5. Available from: https://doi.org/10.1016/j.ijnss.2018.05.001

15. Bui H IA. Antecedents and outcomes of personal mastery: cross-country evidence in Higher Education. Int J Hum Resour Manag. 2013;24-1(January 2015):37-41.

16. Bui HTM, Baruch Y. Learning organizations in higher education: An empirical evaluation within an international context. Manag Learn. 2012;0(0):1-30.

17. Goleman D. Emotional Intelligence: What it can matter more than IQ. New York: Bantam Books; 2001.

18. Zakaria A, Suwandi T, Hargono R. Role of Personal Advanced To Nurse Performance Improvement: Task Performance and Contextual Performance. Int J Adv Res. 2017;5(5):2138-44.

19. Nursalam. Manajemen Keperawatan: Aplikasi dalam Praktik Keperawatan Professional. Edisi 5. Jakarta: Salemba Medika; 2018. 